\title{
Relationship between vestibular dysfunction and quality of life in climacteric women
}

\author{
Relação entre disfunção vestibular e qualidade de vida \\ em mulheres climatéricas
}

Rafaella Silva dos Santos (https://orcid.org/0000-0003-4155-191X) ${ }^{1}$

Mayle Moreira de Andrade (https://orcid.org/0000-0002-6032-6542) ${ }^{2}$

Karyna Myrelly Oliveira Bezerra de Figueiredo Ribeiro (https://orcid.org/0000-0002-5935-6760) ${ }^{1}$

Rafaela Andrade do Nascimento (https://orcid.org/0000-0002-3765-0408) ${ }^{1}$

Mariana Carmen Apolinário Vieira (https://orcid.org/0000-0001-5313-3892) ${ }^{1}$

Saionara Maria Aires da Câmara (https://orcid.org/0000-0002-3054-7213) ${ }^{3}$

Álvaro Campos Cavalcanti Maciel (http://orcid.org/0000-0002-8913-7868) ${ }^{1}$

${ }^{1}$ Departamento de Fisioterapia, Universidade Federal do Rio Grande do Norte (UFRN). Av. Sen. Salgado Filho 3000, Candelária. 59064741 Natal RN Brasil. rafaellassantos@hotmail. com

${ }^{2}$ Departamento de Fisioterapia, Universidade Federal do Ceará. Fortaleza CE Brasil.

${ }^{3}$ Faculdade de Ciências da Saúde do Trairi, UFRN.

Santa Cruz RN Brasil.

\begin{abstract}
The hormonal changes in climacteric women may affect the vestibular system; however, it is not clear in the literature whether the presence of vestibular dysfunction associated with climacteric is related to poorer quality of life. The study sample was composed of 374 women (4065 years). Socioeconomic and demographic data, menopausal status, practice of physical exercises, presence or absence of vestibular dysfunction, hypertension and diabetes, anthropometric measurements and quality of life (using the Utian Quality of Life Scale - UQoL) were collected. Statistical analyses were performed using the Pearson test, Anova, T-test, and multiple regression considering a significance level of 5\%. A significant relationship was found between vestibular dysfunction and health $(p=0.02)$ and emotional $(p=0.01)$ domains of the UQoL. In addition, physical activity, menopausal status, body mass index (BMI), waist-hip ratio (WHR), household income and diastolic blood pressure (DBP) mean also remained significantly related to quality of life. A relationship between vestibular dysfunction and quality of life for health and emotional domains in climacteric women was observed.
\end{abstract}

Key words Climacteric, Vestibular diseases, Quality of life
Resumo Mudanças hormonais em mulheres climatéricas podem afetar o sistema vestibular, porém, não está claro na literatura se a presença da disfunção vestibular associada ao climatério está relacionada à pior qualidade de vida. O objetivo deste artigo é analisar a relação entre disfunção vestibular e qualidade de vida em mulheres climatéricas. Amostra composta por 374 mulheres (40 a 65 anos). Foram coletados dados socioeconômicos e demográficos, status menopausal, prática de exercício físico, presença ou ausência de disfunção vestibular, hipertensão e diabetes, medidas antropométricas e qualidade de vida (por meio do Utian Quality of Life Scale - UQoL). Na análise estatística foi utilizado teste de Pearson, Anova, teste te regressão múltipla, considerando nível de significância de 5\%. Verificou-se relação significativa entre a disfunção vestibular e os domínios saúde ( $p=0,02)$ e emocional $(p=0,01)$ do UQoL. Além disso, atividade fisica, status menopausal, IMC (índice de massa corporal), RCQ (relação cintura-quadril), renda familiar e média da PAD (pressão arterial diastólica) também permaneceram significantemente relacionadas à qualidade de vida. Observou-se relação entre disfunção vestibular e qualidade de vida para os domínios saúde e emocional em mulheres climatéricas.

Palavras-chave Climatério, Doenças vestibulares, Qualidade de vida 


\section{Introduction}

A woman's life period is marked by a gradual cessation of ovarian function, which leads to a transition from pre- to postreproductive status; this is called climacteric ${ }^{1}$. During this period, women are classified into three phases: premenopause, perimenopause and postmenopause ${ }^{2}$.

The decline in ovarian function develops a series of striking physiological events in the climacteric period. This decline leads to estrogen deficiency, which may cause the emergence of urogenital problems such as vaginal dryness and itchiness, and more general symptoms such as hot flashes, night sweats, headaches, dry skin, irritability and sleep disturbance ${ }^{3}$. The above signs and symptoms have a major negative impact on women's quality of life, as reported by some studies $^{4-6}$.

Obesity, hypertension and physical inactivity are important factors to be analyzed in climacteric women, considering that they aggravate the characteristic symptoms of this period and reduce the quality of life of these women ${ }^{7}$. The higher the BMI and the blood pressure, the worse the quality of life is ${ }^{8}$. Physical exercise can effectively improve the symptoms associated with menopause, as well as body weight, BMI and blood lipids. Diabetes, hypertension and body weight are associated with vestibular dysfunction, being important factors to be considered in studies on this subject ${ }^{10-14}$.

Hormonal changes that occur during climacteric may affect the vestibular system, since they act directly on enzymatic processes and neurotransmitter performance, interfering in the homeostasis of the labyrinthine fluids present in the vestibular system ${ }^{15}$. A dysfunction in the vestibular system may lead to vertigo and other types of dizziness, hearing loss, tinnitus, alterations in body balance, gait disturbance, and occasional falls ${ }^{16}$. Moreover, it also interferes in memory, intellect, emotional, vegetative and behavioral reactions, and consequently in the quality of life $^{17}$. Studies in the United States have shown that the prevalence of vestibular dysfunction in adults aged 40 years and above can be as high as $35.4 \%{ }^{11}$, and the women are the most affected population, especially those in the perimenopause period ${ }^{17}$.

Vestibular dysfunction is still a scarcely addressed issue in the literature, and in addition most studies are performed with the elderly/older adults. The authors are unaware of any studies in Brazil that have analyzed the relationship between vestibular dysfunction and quality of life in climacteric women between 40 and 65 years, as proposed in the present study. If this relationship exists, measures can be adopted which improve health and quality of life, and also reduce spending on health services. Therefore, the aim of this study was to analyze the relationship between vestibular dysfunction and quality of life in climacteric women.

\section{Methods}

This is an analytical observational study implementing a transversal approach, reviewed and approved by the Ethics Committee of the Federal University of Rio Grande do Norte, under No. 387.737. Data collection was conducted from April to November 2013, at the Integrated Center for Education, Research, Extension and Community Action (NIPEC), located in Parnamirim (RN).

The initial study sample was comprised of 381 women between 40 and 65 years of age, residing in the municipality of Parnamirim. This age group was established because it represents the usual age range of climacteric occurrence, according to the Ministry of Health ${ }^{18}$. The sample was designed by convenience, however, this sample can be considered representative of the middle-aged women population of Parnamirim who are affected by natural menopause, since they present a similar distribution regarding education and marital status compared to the general population, according to the 2010 census data ${ }^{19}$. The project was advertised in Basic Health Units of the municipality and women interested in participating were invited to the collection site on a given day and time.

The study included women who did not undergo bilateral oophorectomy, with no cognitive alterations, who did not present any neurological or degenerative diseases such as Parkinson's, cerebrovascular accident (CVA), degenerative diseases of the spine, fractured limbs, painful processes or any other condition that could jeopardize the measurement of data identified by the researchers upon first contact or self-report by the participant. Seven women were excluded from the study because they were not able to answer the question regarding a complaint of vestibular/labyrinthine dysfunction, resulting in a final sample of 374 participants. The participants signed a clear and informed consent form of the research, according to the resolution 466/12 of the National Health Council. 
Prior to the data collection, a pilot study was carried out to test variables and calibrate the interviewers. Next, an evaluation of the participants was carried out based on a structured questionnaire, where information on age (years), ethnicity/color (white, pardo or black), years of education (up to seven years of education, more than seven and less than eleven years of education, eleven or more years of education), marital status (stable union or not) and household income (less than three minimum wages, equal to or greater than three minimum wages) were collected. The minimum wage was fixed on an amount of R $\$ 678.00$. Information was obtained by participants' self-reporting.

Menopausal status was determined according to the classification Stages of Reproductive Aging Workshop classification - STRAW ${ }^{2}$. The women were classified into three groups according to the self-report on menstruation pattern: premenopausal (regular menses), perimenopausal (irregular menses, with differences on cycle length over seven days or amenorrhea until one year) or postmenopausal (absence of menses for over one year).

Regular physical exercise practice was self-reported by the participant. In the case of an affirmative answer, they were asked about the type of activity, duration and frequency of practice. Positive responses were considered when exercises were performed for at least 30 minutes, three times per week.

The presence or absence of vestibular dysfunction, hypertension and diabetes were verified by the participant's self-report from having been diagnosed by a physician by the following questions: Has a doctor ever told you that you have vestibular disease or "labyrinthitis"? Has a doctor ever told you that you have diabetes and/ or hypertension? In the case of hypertension it was also considered by measuring their blood pressure (three measurements performed during the evaluation interval of five minutes between them), using an automatic upper arm Omron ${ }^{\circledR}$ blood pressure monitor, clinically validated by the British Hypertension Society (BHS) and the Association for the Advancement of Medical Instrumentation (AAMI). The participant was classified as hypertensive if the average systolic blood pressure (SBP) was $140 \mathrm{mmHg}$ or higher, and/or the average diastolic blood pressure (DBP) was equal or higher than $90 \mathrm{mmHg}^{20}$. In the most recent guideline $(2016)^{21}$, a diagnosis of hypertension occurs when an individual has blood pressure equal to or greater than $140 / 90 \mathrm{mmHg}$ and when they have high cardiovascular risk. The diagnosis also occurs when an individual has blood pressure equal to or greater than $180 / 110 \mathrm{mmHg}$, regardless of their cardiovascular risk ${ }^{21}$.

Anthropometric measures were also analyzed such as weight $(\mathrm{kg})$, using a Wiso ${ }^{\circledR}$ W903 digital scale, and height $(\mathrm{m})$, using a stadiometer. From these measurements, Body Mass Index (BMI - kg/ $\mathrm{m}^{2}$ ) of each participant was calculated. The BMI was categorized according to the World Health Organization (WHO) classification into Normal (18.50 to 24.99), Overweight (25.00 to 29.99), Obese 1 (30.00 to 34.99) and Obese 2 and 3 ( $\geq$ $35.00)^{22}$. Furthermore, hip and waist circumference measurements $(\mathrm{cm})$ were collected using a fiber glass measuring tape, with $1 \mathrm{~mm}$ division $\mathrm{s}^{23}$. For the evaluation, the participants were positioned standing with their arms crossed over their breasts, their feet together and were instructed to relaxed. The waist measurement was performed after expiration, considering the height of the superior iliac crest. The posterior part of the hip of the volunteer was considered for hip measurement ${ }^{23}$. The value of the waist circumference was divided by hip circumference measurements to find the Waist-Hip Ratio (WHR).

Finally, quality of life was assessed using the Utian Quality of Life Scale (UQoL) ${ }^{24}$ adapted and translated for the Brazilian population ${ }^{25}$. It contains 23 questions that comprise four distinct quality of life domains: occupational, health, emotional and sexual. Each question is answered between 1 (very false) and 5 (very true). The higher the score, the better is the assumed quality of life $\mathrm{e}^{24}$.

Data analysis was carried out using SPSS 20.0 software (Statistical Package for the Social Science). Normality of the data was initially verified by the Kolmogorov-Smirnov test. Statistical descriptive measures of central tendency (mean) and dispersion (standard deviation) were used for quantitative variables, and absolute and relative frequencies for categorical variables. In the bivariate analysis, the relationship between categorical variables and the quality of life was assessed using the t-test or analysis of variance - ANOVA, according to the categories of the variables. The Pearson correlation test was used for analysis of the quantitative variables and quality of life. The ratio between vestibular dysfunction and quality of life (total score and domains) was analyzed using the t-test. Finally, multiple linear regression models were performed, including variables with $\mathrm{p}<0.20$ in the bivariate analysis. A significance level of $5 \%$ was considered for all tests. 


\section{Results}

The sample was comprised of 374 women, in which it was found that $47.8 \%$ of women were in the postmenopausal stage and $74.1 \%$ did not practice physical exercises. In relation to clinical conditions, hypertension was observed in 51.9\% of women and $89.8 \%$ was not diabetic. The other characteristics are presented in Table 1.

Table 2 shows the analysis between the presence or absence of vestibular dysfunction and quality of life, in which $88(23.5 \%)$ women reported having dysfunction. A relationship between vestibular dysfunction and quality of life for health ( $p$-value 0.03 ) and emotional ( $p$-value 0.006) domains was found.

Regarding to bivariate analysis between the quantitative variables (age, mean SBP, mean DBP, BMI, WHR) and the quality of life, mean systolic and diastolic blood pressure were correlated with occupational, health and total UQoL score domains, and mean diastolic pressure was also correlated with the emotional domain. As a result, all correlations were found to be weak. Other results are displayed in Table 3.

In the bivariate analysis between the categorical variables (ethnicity, years of education, marital status, household income, menopausal status, physical exercise, hypertension, diabetes) and the quality of life, a relation between physical exercise and quality of life was verified for the health, emotional and total UQoL score domains, and between hypertension and quality of life according to the occupational, health, emotional and total score domains (Table 4).

After multiple linear regression analysis, vestibular dysfunction remained related to the health $(p=0.02)$ and emotional $(p=0.01)$ domains, being the variables that remained statistically significant in the final model (Table 5).

The following variables remained significantly related to the health domain: vestibular dysfunction, physical activity, menopausal status, BMI and WHR. Regarding the vestibular dysfunction, it was observed that women with no such dysfunction had better quality of life. Absence of regular physical exercise, higher BMI and higher WHR were related to poorer quality of life. Moreover, women in pre and perimenopausal stages had worse quality of life in relation to postmenopausal women.

Regarding the emotional domain, the variables that remained related were: vestibular dysfunction, household income and mean DBP. Once again, absence of vestibular dysfunction
Table 1. Sample characterization. Parnamirim, RN, $2016(\mathrm{n}=374)$

\begin{tabular}{|c|c|}
\hline Variables & $\begin{array}{c}\text { Mean (SD) or } \\
\text { n (\%) }\end{array}$ \\
\hline Age & $50.3(5.6)$ \\
\hline \multicolumn{2}{|l|}{ Ethnicity/color ${ }^{*}$} \\
\hline White & $141(37.8)$ \\
\hline Pardo & $209(56.0)$ \\
\hline Black & $23(6.2)$ \\
\hline \multicolumn{2}{|l|}{ Years of education } \\
\hline Up to seven years of education & $158(42.2)$ \\
\hline $\begin{array}{l}\text { More than seven and less than } \\
\text { eleven years of education }\end{array}$ & $157(42.0)$ \\
\hline Eleven or more years of education & $59(15.8)$ \\
\hline \multicolumn{2}{|l|}{ Marital status } \\
\hline Yes & $273(73.0)$ \\
\hline No & $101(27.0)$ \\
\hline \multicolumn{2}{|l|}{ Household income } \\
\hline$<3$ minimum wages & $260(69.5)$ \\
\hline$\geq 3$ minimum wages & $114(30.5)$ \\
\hline \multicolumn{2}{|l|}{ Menopausal status ${ }^{*}$} \\
\hline Premenopausal & $77(20.8)$ \\
\hline Perimenopausal & $116(31.4)$ \\
\hline Postmenopausal & $177(47.8)$ \\
\hline \multicolumn{2}{|l|}{ Physical exercise } \\
\hline Yes & $97(25.9)$ \\
\hline No & $277(74.1)$ \\
\hline \multicolumn{2}{|l|}{ Hypertension } \\
\hline Yes & $194(51.9)$ \\
\hline No & $180(48.1)$ \\
\hline \multicolumn{2}{|l|}{ Diabetes } \\
\hline Yes & $38(10.2)$ \\
\hline No & $336(89.8)$ \\
\hline Mean SBP & $135.54(18.5)$ \\
\hline Mean DBP & $81.21(9.7)$ \\
\hline BMI $\left(\mathrm{kg} / \mathrm{m}^{2}\right)$ & $28.73(4.8)$ \\
\hline WHR & $0.91(0.06)$ \\
\hline
\end{tabular}

was related to better quality of life. Lower income and higher DBP means were related to poorer quality of life. Regarding the total score, higher DBP means remained related to poorer quality of life.

\section{Discussion}

This study found a significant relationship between the presence of vestibular dysfunction and worse quality of life in the health and emotional domains of the UQoL. In addition, physical ac- 
Table 2. Analysis between quality of life and presence or absence of vestibular dysfunction.

\begin{tabular}{|c|c|c|c|c|}
\hline & \multicolumn{2}{|c|}{ Vestibular dysfunction } & \multirow[b]{2}{*}{ Total $(n=374)$} & \\
\hline & $\begin{array}{c}\text { Yes } \\
\mathbf{n}=\mathbf{8 8}(23.5 \%)\end{array}$ & $\begin{array}{c}\text { No } \\
\mathrm{n}=286(76.5 \%)\end{array}$ & & \\
\hline Quality of life & Mean $(S D)$ & Mean $(S D)$ & Mean (SD) & p-value \\
\hline UQoL - Occupational & $26.2(4.22)$ & $26.0(4.40)$ & $26.0(4.33)$ & $0.60^{\mathrm{a}}$ \\
\hline UQoL - Health & $17.4(4.60)$ & $18.6(5.23)$ & $18.3(5.10)$ & $0.03^{\mathrm{a}}$ \\
\hline UQoL - Emotional & $19.4(4.00)$ & $20.8(3.93)$ & $20.5(4.00)$ & $0.006^{\mathrm{a}}$ \\
\hline UQoL - Sexual & $8.5(2.91)$ & $8.9(3.20)$ & $8.8(3.11)$ & $0.32^{\mathrm{a}}$ \\
\hline UQoL - Total & $71.6(9.91)$ & $74.3(11.60)$ & $73.6(11.28)$ & $0.05^{\mathrm{a}}$ \\
\hline
\end{tabular}

UQOL - Utian Quality of Life Scale. ${ }^{a}$ - p-value for Student Test T.

Table 3. Bivariate analysis between age, mean SBP, mean DBP, BMI, WHR and the quality of life.

\begin{tabular}{cccccc}
\hline Variables & $\begin{array}{c}\text { UQoL } \\
\text { Occupational }\end{array}$ & $\begin{array}{c}\text { UQoL } \\
\text { Health }\end{array}$ & $\begin{array}{c}\text { UQoL } \\
\text { Emotional }\end{array}$ & $\begin{array}{c}\text { UQoL } \\
\text { Sexual }\end{array}$ & $\begin{array}{c}\text { UQoL } \\
\text { Total }\end{array}$ \\
\hline Age (years) & $\mathrm{r}=-0.05$ & $\mathrm{r}=0.06$ & $\mathrm{r}=0.03$ & $\mathrm{r}=-0.05$ & $\mathrm{r}=0.004$ \\
& $\mathrm{p}=0.25^{\mathrm{a}}$ & $\mathrm{p}=0.21^{\mathrm{a}}$ & $\mathrm{p}=0.46^{\mathrm{a}}$ & $\mathrm{p}=0.26^{\mathrm{a}}$ & $\mathrm{p}=0.93^{\mathrm{a}}$ \\
Mean SBP & $\mathrm{r}=-0.22$ & $\mathrm{r}=-0.11$ & $\mathrm{r}=-0.08$ & $\mathrm{r}=0.02$ & $\mathrm{r}=-0.15$ \\
& $\mathrm{p}<0.001^{\mathrm{a}}$ & $\mathrm{p}=0.03^{\mathrm{a}}$ & $\mathrm{p}=0.10^{\mathrm{a}}$ & $\mathrm{p}=0.58^{\mathrm{a}}$ & $\mathrm{p}=0.002^{\mathrm{a}}$ \\
Mean DBP & $\mathrm{r}=-0.21$ & $\mathrm{r}=-0.14$ & $\mathrm{r}=-0.13$ & $\mathrm{r}=-0.02$ & $\mathrm{r}=-0.20$ \\
& $\mathrm{p}<0.001^{\mathrm{a}}$ & $\mathrm{p}=0.004^{\mathrm{a}}$ & $\mathrm{p}=0.01^{\mathrm{a}}$ & $\mathrm{p}=0.60^{\mathrm{a}}$ & $\mathrm{p}<0.001^{\mathrm{a}}$ \\
BMI (Kg/m $\left.{ }^{2}\right)$ & $\mathrm{r}=-0.01$ & $\mathrm{r}=-0.28$ & $\mathrm{r}=0.01$ & $\mathrm{r}=0.02$ & $\mathrm{r}=-0.12$ \\
& $\mathrm{p}=0.78^{\mathrm{a}}$ & $\mathrm{p}<0.001^{\mathrm{a}}$ & $\mathrm{p}=0.81^{\mathrm{a}}$ & $\mathrm{p}=0.67^{\mathrm{a}}$ & $\mathrm{p}=0.01^{\mathrm{a}}$ \\
WHR & $\mathrm{r}=0.02$ & $\mathrm{r}=-0.22$ & $\mathrm{r}=0.009$ & $\mathrm{r}=-0.02$ & $\mathrm{r}=-0.09$ \\
& $\mathrm{p}=0.66^{\mathrm{a}}$ & $\mathrm{p}<0.001^{\mathrm{a}}$ & $\mathrm{p}=0.85^{\mathrm{a}}$ & $\mathrm{p}=0.69^{\mathrm{a}}$ & $\mathrm{p}=0.06^{\mathrm{a}}$ \\
\hline
\end{tabular}

SBP - Systolic blood pressure; DBP - Diastolic blood pressure; BMI - Body Mass Index; WHR - Waist/hip ratio; UQOL - Utian Quality of Life Scale. ${ }^{\text {a }}$ - p-value for Pearson Correlation

tivity, menopausal status, BMI, WHR, household income and mean DBP also remained significantly related to quality of life.

A study ${ }^{26}$ that evaluated 60 patients ( 32 were women) with vestibular dysfunction and mean age of 50 years also found a negative influence of vestibular dysfunction on quality of life related to emotional aspects, mental health and overall health of these individuals, as well as limitations in activities of daily living, decreased functional capacity, vitality and social aspects ${ }^{26}$. Women with vestibular dysfunction, especially those in the period of perimenopause, may present complaints of dizziness, instability, oscillia (illusion of motionless surrounding objects moving), spatial disorientation and change in the vertical position feeling, in addition to evident neurovegetative component, emotional disturbances, depression and anxiety ${ }^{17}$.

A significant relationship between not practicing regular exercises and worse quality of life was observed in the health domain of the UQoL questionnaire. Corroborating this result, Guimarães \& Baptista ${ }^{27}$ evaluated 1,011 women at all stages of menopause and found that those who practiced regular exercise had lower scores on the climacteric symptoms and better quality of life. Physical exercise promotes greater activation of the vestibular system, improving its function and reducing the symptoms of vestibular dysfunction $^{28}$. Individuals with vestibular dysfunction often restrict travel, social commitments and physical activity to avoid symptoms ${ }^{29,30}$. As a consequence, these individuals may have reduced physical fitness, and may become more sedentary.

Regarding menopausal status, a significant relationship was found between being in the pre and perimenopausal period and having poorer quality of life in the health domain, possibly due to the fact that women in these periods are still not used to the signs and symptoms of menopause. In contrast, a study found no significant difference between the menopausal stage and the quality of life of women ${ }^{31}$. However, the sample 
Table 4. Bivariate analysis between variables ethnicity, years of education, marital status, household income, menopausal status, physical exercise, hypertension, diabetes and quality of life.

\begin{tabular}{|c|c|c|c|c|c|}
\hline Variables & $\begin{array}{c}\text { UQoL } \\
\text { Occupational } \\
\text { Mean (SD) }\end{array}$ & $\begin{array}{c}\text { UQoL } \\
\text { Health } \\
\text { Mean (SD) }\end{array}$ & $\begin{array}{c}\text { UQoL } \\
\text { Emotional } \\
\text { Mean (SD) }\end{array}$ & $\begin{array}{c}\text { UQoL } \\
\text { Sexual } \\
\text { Mean (SD) }\end{array}$ & $\begin{array}{c}\text { UQoL } \\
\text { Total } \\
\text { Mean }(\mathrm{SD})\end{array}$ \\
\hline \multicolumn{6}{|l|}{ Ethnicity/color } \\
\hline White & $25.56(4.40)$ & $18.33(5.12)$ & $19.92(3.97)$ & $8.45(3.00)$ & $72.27(11.87)$ \\
\hline Pardo & $26.15(4.30)$ & $18.36(5.25)$ & $20.86(3.93)$ & $8.96(3.17)$ & $74.35(11.20)$ \\
\hline Black & $27.39(3.94)$ & $18.17(3.72)$ & $20.48(4.13)$ & $9.61(3.04)$ & $75.65(7.12)$ \\
\hline p-value & $0.13^{\mathrm{a}}$ & $0.98^{\mathrm{a}}$ & $0.10^{\mathrm{a}}$ & $0.14^{\mathrm{a}}$ & $0.16^{\mathrm{a}}$ \\
\hline \multicolumn{6}{|l|}{ Years of education } \\
\hline $\begin{array}{l}\text { Up to seven years of } \\
\text { education }\end{array}$ & $25.85(4.24)$ & $17.88(4.65)$ & $19.66(3.79)$ & $8.99(2.97)$ & $72.38(10.72)$ \\
\hline $\begin{array}{l}\text { More than seven and } \\
\text { less than eleven years of } \\
\text { education }\end{array}$ & $25.99(4.52)$ & $18.93(5.38)$ & $20.99(3.90)$ & $8.82(3.10)$ & $74.76(11.59)$ \\
\hline $\begin{array}{l}\text { Eleven or more years of } \\
\text { education }\end{array}$ & $26.55(4.07)$ & $17.98(5.43)$ & $21.28(4.28)$ & $8.22(3.45)$ & $74.03(11.70)$ \\
\hline $\mathrm{p}$-value & $0.57^{\mathrm{a}}$ & $0.16^{\mathrm{a}}$ & $0.003^{\mathrm{a}}$ & $0.27^{\mathrm{a}}$ & $0.17^{\mathrm{a}}$ \\
\hline \multicolumn{6}{|l|}{ Marital status } \\
\hline Yes & $25.74(4.40)$ & $18.04(5.14)$ & $20.29(3.90)$ & $9.15(2.99)$ & $73.23(11.51)$ \\
\hline No & $26.80(4.05)$ & $19.14(4.94)$ & $20.97(4.13)$ & $7.85(3.22)$ & $74.76(10.56)$ \\
\hline p-value & $0.03^{\mathrm{b}}$ & $0.06^{\mathrm{b}}$ & $0.14^{\mathrm{b}}$ & $<0.001^{\mathrm{b}}$ & $0.25^{\mathrm{b}}$ \\
\hline \multicolumn{6}{|l|}{ Household income } \\
\hline$<3$ minimum wages & $25.71(4.38)$ & $18.04(4.94)$ & $19.93(3.85)$ & $8.55(3.00)$ & $72.24(10.84)$ \\
\hline$\geq 3$ minimum wages & $26.71(4.16)$ & $19.02(5.41)$ & $21.71(3.99)$ & $9.38(3.29)$ & $76.81(11.64)$ \\
\hline p-value & $0.04^{\mathrm{b}}$ & $0.09^{\mathrm{b}}$ & $<0.001^{\mathrm{b}}$ & $0.01^{\mathrm{b}}$ & $<0.001^{\mathrm{b}}$ \\
\hline \multicolumn{6}{|l|}{ Menopausal status } \\
\hline Premenopausal & $26.30(4.63)$ & $18.01(5.45)$ & $20.41(3.63)$ & $9.19(3.22)$ & $73.91(11.59)$ \\
\hline Perimenopausal & $26.33(4.16)$ & $17.59(4.58)$ & $20.41(3.70)$ & $8.73(3.23)$ & $73.08(11.13)$ \\
\hline Postmenopausal & $25.67(4.33)$ & $18.99(5.25)$ & $20.57(4.25)$ & $8.68(3.00)$ & $73.92(11.34)$ \\
\hline $\mathrm{p}$-value & $0.37^{\mathrm{a}}$ & $0.06^{\mathrm{a}}$ & $0.92^{\mathrm{a}}$ & $0.48^{\mathrm{a}}$ & $0.81^{\mathrm{a}}$ \\
\hline \multicolumn{6}{|l|}{ Physical exercise } \\
\hline Yes & $26.64(4.44)$ & $21.78(5.13)$ & $21.21(4.21)$ & $9.21(3.08)$ & $78.83(11.63)$ \\
\hline No & $25.80(4.28)$ & $17.12(4.51)$ & $20.21(3.86)$ & $8.66(3.11)$ & $71.79(10.56)$ \\
\hline p-value & $0.10^{\mathrm{b}}$ & $<0.001^{\mathrm{b}}$ & $0.03^{\mathrm{b}}$ & $0.13^{\mathrm{b}}$ & $<0.001^{\mathrm{b}}$ \\
\hline \multicolumn{6}{|l|}{ Hypertension } \\
\hline Yes & $25.30(4.27)$ & $17.69(4.77)$ & $19.90(3.84)$ & $8.74(2.92)$ & $71.63(10.37)$ \\
\hline No & $26.80(4.27)$ & $19.04(5.37)$ & $21.10(4.03)$ & $8.86(3.30)$ & $75.83(11.83)$ \\
\hline p-value & $0.001^{\mathrm{b}}$ & $0.01^{\mathrm{b}}$ & $0.004^{\mathrm{b}}$ & $0.71^{\mathrm{b}}$ & $<0.001^{\mathrm{b}}$ \\
\hline \multicolumn{6}{|l|}{ Diabetes } \\
\hline Yes & $25.87(4.08)$ & $17.47(5.04)$ & $20.82(4.13)$ & $8.13(2.98)$ & $72.29(10.47)$ \\
\hline No & $26.06(4.34)$ & $18.52(5.22)$ & $20.45(3.98)$ & $8.93(3.06)$ & $73.97(11.40)$ \\
\hline p-value & $0.80^{\mathrm{b}}$ & $0.24^{\mathrm{b}}$ & $0.60^{\mathrm{b}}$ & $0.13^{\mathrm{b}}$ & $0.38^{\mathrm{b}}$ \\
\hline
\end{tabular}

UQOL - Utian Quality of Life Scale. ${ }^{\mathrm{a}}$ - p-value for ANOVA. $^{\mathrm{b}}$ - p-value for Student Test T.

was composed by Turkish women and the author reports that one of the reasons why these women face this period more easily could be their point of view on menopause as being a natural and expected event ${ }^{31}$.

The results of anthropometric measurements showed that the mean BMI of women participat- ing in the study fits within "pre-obese" according to the WHO classification, being related to a higher risk of presenting comorbidities ${ }^{32}$. The measurement of participants' waist circumference represents a substantially increased risk value (average $95 \mathrm{~cm}$ ) for metabolic complications ${ }^{33}$. Similarly, WHR shows increased risk for obesity 


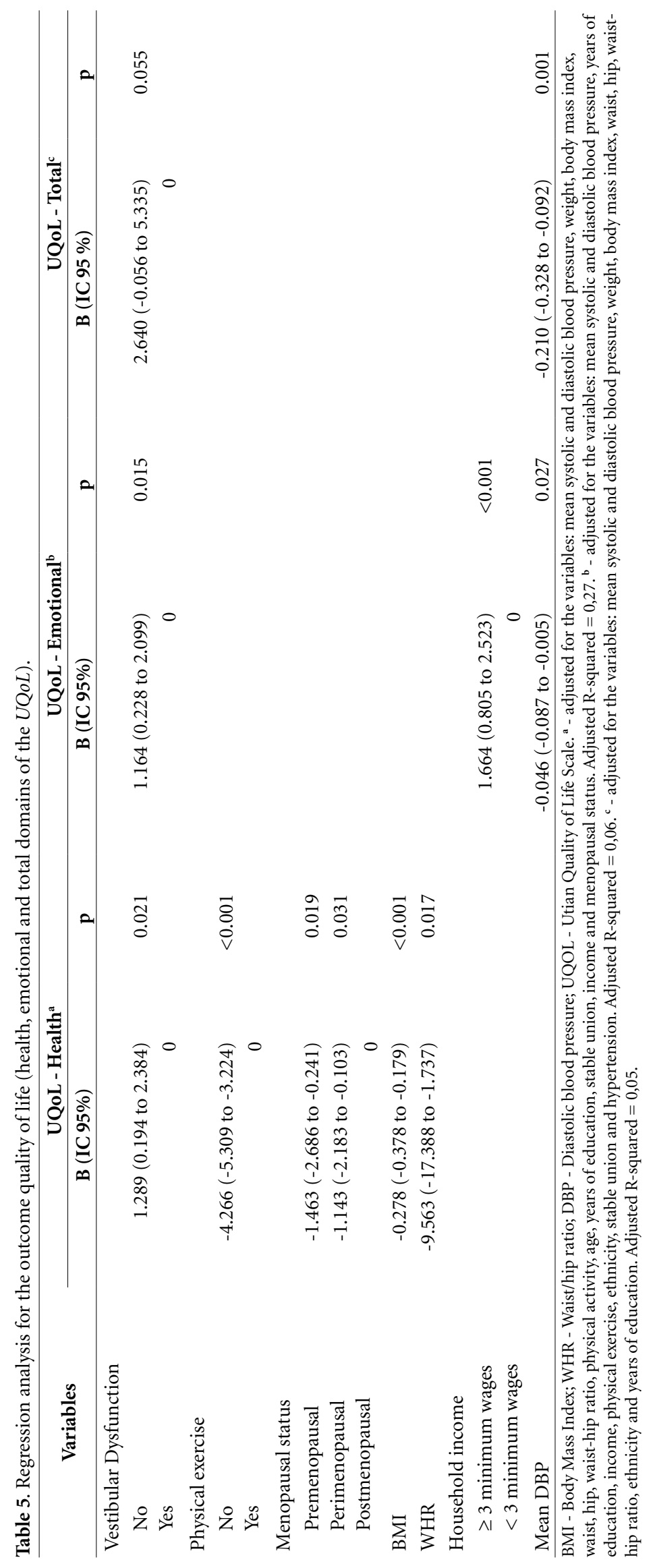


and metabolic syndrome ${ }^{29}$. Hypoestrogenism in climacteric women is largely responsible for weight gain and abdominal fat due changes in the metabolic profile ${ }^{34}$. Thus, overweight and obesity associated with menopause require increased attention to women's health ${ }^{5}$. Also, perimenopause constitutes a milestone of decadence and loss of feminine values; it is a phase where feelings of fear and apprehension are expected due to hormonal changes, an emergence of symptoms, and aesthetic, psychological and social changes, with worsening in the quality of life ${ }^{35}$.

BMI and WHR anthropometric variables were correlated to the health domain of quality of life, where the higher these variables, the worse the quality of life for that domain. These data corroborate Coakley et al. ${ }^{36}$, who evaluated 56,510 women aged between 45 and 71 years and found that excess weight contributed to poorer health and quality of life due to limitations in common daily activities, reduced vitality and increased perceived fatigue. One study verified that the body weight of individuals was significantly associated with vestibular dysfunction ${ }^{14}$.

There is association between climacteric and the central adiposity increasing, which favors a higher risk to cardiovascular events and metabolic disturbances ${ }^{34}$. Literature shows that metabolic diseases, overweight and sedentary lifestyle are strongly related do vestibular diseases ${ }^{37,38}$. Some medications may affect the normal functioning of the vestibular system and cause dizziness ${ }^{39}$, and those people with metabolic syndrome need to use daily medications. Moreover, the sedentary lifestyle is an important risk factor to the dizziness arising, which leads to inactivity and vestibular reflexes inhibition, fear andlor loss of self-confidence ${ }^{40}$.

Regarding household income, a significant relationship was found between having a higher income and having better quality of life for the emotional domain. Have a higher income has been associated with greater access to information, leisure, better educational levels, greater job stability, providing a greater sense of security and well-being in dealing with the physical changes and climacteric symptoms ${ }^{41}$. Corroborating the present findings, Genazzani et al. ${ }^{42}$ analyzed 2,160 women in perimenopause and postmenopause periods and concluded that women with higher incomes tend to have higher levels of physical and psychological well-being, less disorders related to menopause and better quality of life.
In relation to clinical conditions, approximately half of the women studied were considered hypertensive, with a significant relationship between higher mean DBP and worse quality of life for the emotional domain and total score of the UQoL questionnaire. Some studies have found that hypertension is significantly associated with vestibular dysfunction ${ }^{11-13}$. According to Tan et al. ${ }^{10}$, hypertension was associated with an increased odds ratio for vestibular dysfunction, although neither association reached statistical significance.

The present study has a limitation of there being a lack of specific complementary tests of the vestibular system to confirm the clinical diagnosis of vestibular dysfunction; its presence or absence was assessed by participant self-reporting regarding their medical diagnosis of the dysfunction's presence. However, self-reporting questionnaires are widely used in epidemiological studies ${ }^{43-45}$ and the present study is a sample of predominantly middle-aged women. Thus, the possibility of bias due to lack of understanding of the questions is low, which could occur in studies with an older population sample ${ }^{46}$. The importance of this study should be emphasized, considering there are few studies on the relationship between vestibular dysfunction and quality of life in middle-aged women experiencing the climacteric.

\section{Conclusion}

A relation between vestibular dysfunction and quality of life for the health and emotional domains in climacteric women was observed, with worse quality of life for those who reported vestibular dysfunction being verified, even after adjusting for covariables (physical activity, menopausal status, BMI, WHR, household income and mean DBP). We hope to highlighted the negative consequences in quality of life of climacteric women with vestibular dysfunction on the collective health field, since this population may be a target for public health programs seeking to prevent and treat the climacteric and vestibular dysfunction symptoms. Finally, we suggest that further longitudinal studies are performed with a comprehensive assessment containing a collection of the clinical history of vertigo of participants in conjunction with specific tests of the vestibular system to confirm the results found in order to establish a cause-and-effect relationship. 


\section{Collaborations}

RS Santos was responsible for the acquisition of data analysis, interpretation of data analysis, drafting the article and critical revision. MM Andrade was responsible for the acquisition of data analysis, interpretation of data analysis and drafting the article. KMOBF Ribeiro was responsible for interpretation of data analysis, drafting the article and critical revision. RA Nascimento and MCA Vieira was responsible for the acquisition of data analysis and interpretation of data analysis. SMA Câmara was responsible for the concept and design of the study and acquisition of data analysis. ACC Maciel was responsible for the concept and design of the study and critical revision. All the authors gave the final approval of the version to be published.

\section{References}

1. Sievert LL. Menopause across cultures: clinical considerations. Menopause 2014; 21(4):421-423.

2. Harlow SD, Gass M, Hall JE, Lobo R, Maki P, Rebar RW, Sherman S, Sluss PM, de Villiers TJ; STRAW + 10 Collaborative Group. Executive summary of the Stages of Reproductive Aging Workshop + 10: addressing the unfinished agenda of staging reproductive aging. $J$ Clin Endocrinol Metab 2012; 97(4):1159-1168.

3. Nelson HD. Menopause. Lancet 2008; 371(9614):760770 .

4. Sorpreso IC, Soares Júnior JM, Fonseca AM, Baracat EC. Female aging. Rev Assoc Med Bras 2015; 61(6):553-556.

5. Gonçalves JT, Silveira MF, Campos MC, Costa LH. Overweight and obesity and factors associated with menopause. Cien Saude Colet 2016; 21(4):1145-1156.

6. Abdullah B, Moize B, Ismail BA, Zamri M, Mohd Nasir NF. Prevalence of menopausal symptoms, its effect to quality of life among Malaysian women and their treatment seeking behaviour. Med J Malaysia 2017; 72(2):94-99.

7. Blümel JE, Chedraui P, Aedo S, Fica J, Mezones-Holguín E, Barón G, Bencosme A, Benítez Z, Bravo LM, Calle A, Flores D, Espinoza MT, Gómez G, Hernández-Bueno JA, Laribezcoa F, Martino M, Lima S, Monterrosa A, Mostajo D, Ojeda E, Onatra W, Sánchez H, Tserotas K, Vallejo MS, Witis S, Zúñiga MC. Obesity and its relation to depressive symptoms and sedentary lifestyle in middle-aged women. Maturitas 2015; 80(1):100-105

8. Garin N, Olava B, Moneta MV, Miret M, Lobo A, Ayuso-Mateos JL, Haro JM. Impact of multimorbidity on disability and quality of life in the Spanish older population. PLoS One 2014; 9(11):111498.

9. Zhang J, Chen G, Lu W, Yan X, Zhu S, Dai Y, Xi S, Yao C, Bai W. Effects of physical exercise on health-related quality of life and blood lipids in perimenopausal women: a randomized placebo-controlled trial. Menopause 2014; 21(12):1269-1276.

10. Tan JL, Tang J, Lo S, Yeak S. Investigating the risk factors of vestibular dysfunction and the relationship with presbyacusis in Singapore. J Laryngol Otol 2016; 130(9):816-821.

11. Agrawal Y, Carey JP, Della Santina CC, Schubert MC Minor LB. Disorders of balance and vestibular function in US adults: data from the National Health and Nutrition Examination Survey, 2001-2004. Arch Intern Med 2009; 169:938-944.
12. De Stefano A, Dispenza F, Suarez H, Perez-Fernandez N, Manrique-Huarte R, Ban JH, Kim MB, Strupp M, Feil K, Oliveira CA, Sampaio AL, Araujo MF, Bahmad Junior F, Ganança MM, Ganança FF, Dorigueto R, Lee H, Kulamarva G, Mathur N, Di Giovanni P, Petrucci AG, Staniscia T, Citraro L, Croce A. A multicenter observational study on the role of comorbidities in the recurrent episodes of benign paroxysmal positional vertigo. Auris Nasus Larynx 2014; 41(1):31-36.

13. Neuhauser HK, von Brevern M, Radtke A, Lezius F, Feldmann M, Ziese T, Lempert T. Epidemiology of vestibular vertigo: a neurotologic survey of the general population. Neurology 2005; 65(6):898-904

14. Koo JW, Chang MY, Woo SY, Kim S, Cho YS. Prevalence of vestibular dysfunction and associated factors in South Korea. BMJ Open 2015; 5(10):e008224.

15. Isbii C, Nisbino LK, Campos CAH. Vestibular characterization in the menstrual cycle. Braz J Otorhinolaryngol 2009; 75(3):375-380.

16. Gazzola JM, Perracini MR, Ganança MM, Ganança FF. Functional balance associated factors in the elderly with chronic vestibular disorder. Braz J Otorhinolaryngol 2006; 72(5):683-690.

17. Korsunska LL, Meshcheryakova AV. The epidemiology of vestibular dysfunction in women with perimenopausal period. Int J Clin Exp Med 2013; 3(1-2):14-17.

18. Brasil. Ministério da Saúde (MS), Instituto Sírio-Libanês de Ensino e Pesquisa. Protocolos da Atenção Básica: Saúde das Mulheres. Brasília: MS; 2016. [cited 2018 Feb 20]. Available in: http://189.28.128.100/dab/ docs/portaldab/publicacoes/protocolo_saude_mulher.pdf

19. Câmara SM, Zunzunegui MV, Pirkle C, Moreira MA, Maciel AC. Menopausal status and physical performance in middle aged women: a cross-sectional community-based study in Northeast Brazil. PLoS One 2015; 10(3): $\mathrm{e} 0119480$.

20. Weber MA, Schiffrin EL, White WB, Mann S, Lindholm LH, Kenerson JG, Flack JM, Carter BL, Materson BJ, Ram CV, Cohen DL, Cadet JC, Jean-Charles RR, Taler S, Kountz D, Townsend RR, Chalmers J, Ramirez AJ, Bakris GL, Wang J, Schutte AE, Bisognano JD, Touyz RM, Sica D, Harrap SB. Clinical practice guidelines for the management of hypertension in the community: a statement by the American Society of Hypertension and the International Society of Hypertension. J Clin Hypertens (Greenwich) 2014; 16(1):14-26. 
21. Malachias MVB, Gomes MAM, Nobre F, Alessi A, Feitosa AD, Coelho EB. 7th Brazilian Guideline of Arterial Hypertension: Chapter 2 - Diagnosis and Classification. Arq Bras Cardiol 2016; 107(3 Suppl 3):7-13.

22. World Health Organization (WHO). Global database on Body Mass Index. [cited 2017 Sep 18]. Available in: http://apps.who.int/bmi/index.jsp?introPage =intro_3.html.

23. Lean ME, Han TS, Morrison CE. Waist circumference as a measure for indicating need for weight management. BMJ 1995; 311(6998):158-161.

24. Utian WH, Janata JW, Kingsberg SA, Schlutcher M, Hamilton JC. The Utian Quality of Life (UQoL) scale: development and validation of an instrument to quantify quality of life through and beyond menopause. Menopause 2002; 9(6):402-410.

25. Lisboa LL, Utian W, Fonseca Filho GG, Azevedo GD. Translation, adaptation and validation of the Brazilian version of the Utian Quality of Life for evaluation of quality of life in the climacteric. Rev Bras Ginecol Obstet 2015; 37(11):520-525.

26. Vaz AC, Oliveira APR. Impact of the vertigo in the quality of life in patients with vestibular dysfunction. Fisioter Mov 2007; 20:71-76.

27. Guimarães ACA, Baptista F. Relationship between physical activity and menopausal symptoms. Rev Bras Ativ Fis Saude 2011; 16:144-149.

28. Smith PF. Is hippocampal neurogenesis modulated by the sensation of self-motion encoded by the vestibular system? Neurosci Biobehav Rev 2017; 83:489-495.

29. Jacobson GP, Calder JH. Self-perceived balance disability/handicap in the presence of bilateral peripheral vestibular system impairment. J Am Acad Audiol 2000; 11(2):76-83.

30. Patatas OHG, Ganança CF, Ganança FF. Quality of life of individuals submitted to vestibular rehabilitation. Braz J Otorhinolaryngol 2009; 75(3):387-394.

31. Ozkan S, Erkan SA, Zencir M. Women's quality of life in the premenopausal and postmenopausal periods. Qual Life Res 2005; 14(8):1795-1801.

32. World Health Organization (WHO). Obesity: preventing and managing the global epidemic. Report of a WHO Consultation. World Health Organ Tech Rep Ser 2000; 894:i-xii, 1-253.

33. I Diretriz Brasileira de Diagnóstico e Tratamento da Síndrome Metabólica. Rev Soc Bras Hipert 2004; 17.

34. Achie L, Olorunshola K, Toryila J, Tende JA. The Body Mass Index, Waist Circumference and Blood Pressure of Postmenopausal Women in Zaria, Northern Nigeria. Curr Res J Biol Sci 2012; 4:329-332.

35. Nachtigall LE, Nachtigall MJ. Menopausal Changes, quality of life, and hormone therapy. Clin Obstet Gynecol 2004; 47(2):485-488.

36. Coakley EH, Kawachi I, Manson JE, Speizer FE, Willet WC, Colditz GA. Lower levels of physical functioning are associated with higher body weight among middle-aged and older women. Int J Obes Relat Metab Disord 1998; 22(10):958-965.

37. Gazzola JM, Ganança FF, Aratani MC, Perracini MR, Ganança MM. Clinical evaluation of elderly people with chronic vestibular disorder. Braz J Otorhinolaryngol 2006; 72(4):515-522.
38. Moreira Bittar RS, Simoceli L, Bovino Pedalini ME, Bottino MA. The treatment of diseases related to balance disorders in the elderly and the effectiveness of vestibular rehabilitation. Braz J Otorhinolaryngol 2007; 73(3):295-298.

39. Maarsingh OR, Dros J, Schellevis FG, van Weert HC, van der Windt DA, der Riet G, van der Horst HE. Causes of Persistent Dizziness in Elderly Patients in Primary Care. Ann Fam Med 2010; 8(3):196-205.

40. Silva CN, Ribeiro KMOBF, Freitas RVM, Ferreira LMBM, Guerra RO. Vertiginous Symptoms and Objective Measures of Postural Balance in Elderly People with Benign Paroxysmal Positional Vertigo Submitted to the Epley Maneuver. Int Arch Otorhinolaryngol 2016; 20(1):61-68.

41. Kakkar V, Kaur D, Chopra K, Kaur A, Kaur IP. Assessment of the variation in menopausal symptoms with age, education and working/non-working status in north-Indian sub population using menopause rating scale (MRS). Maturitas 2007; 57(3):306-314.

42. Genazzani AR, Nicolucci A, Campagnoli C, Crosignani P, Nappi C, Serra GB, Bottiglioni E, Cianci A, De Aloysio D, Donati Sarti C, Gambacciani M, Monteleone P, Genazzani AD, Guaschino S, Palumbo G, Petraglia F, Schonauer S, Volpe A, Di Paolantonio T, Nagni M, Tempesta A, Coronel GA; Progetto Donna Qualità della Vita Working Group. Assessment of the QoL in Italian menopausal women: comparison between HRT users and non-users. Maturitas 2002; 42(4):267-280.

43. Andrade JM, Rios LR, Teixeira LS, Vieira FS, Mendes DC, Vieira MA, Silveira MF. Influence of socioeconomic factors on the quality of life of elderly hypertensive individuals. Cien Saude Colet 2014; 19(8):3497-3504.

44. Pimenta FB, Pinho L, Silveira MF, Botelho AC. Factors associated with chronic diseases among the elderly receiving treatment under the Family Health Strategy. Cien Saude Colet 2015; 20(8):2489-2498.

45. Miranda LC, Soares SM, Silva PA. Quality of life and associated factors in elderly people at a Reference Center. Cien Saude Colet 2016; 21(11):3533-3544.

46. Murray KJ, Hill K, Phillips B, Waterson J. A pilot study of falls risk and vestibular dysfunction in older fallers presenting to hospital emergency departments. Disabil Rehabil 2005; 27(9):499-506.

Article submitted 06/07/2017

Approved 08/06/2018

Final version submitted10/06/2018 